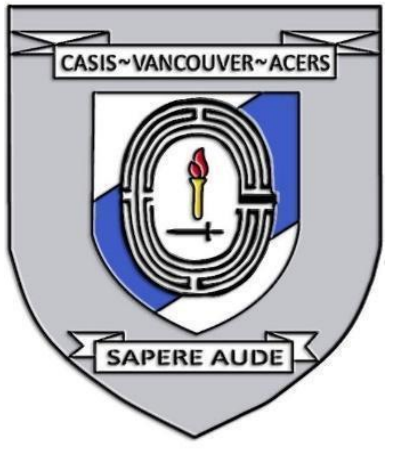

\title{
THE USE OF MEMES AND SATIRE BY THE \\ ALT-RIGHT AND GEN Z ACTIVISTS - EXCLUSION VS INCLUSION
}

Date: November $27^{\text {th }}, 2020$

Disclaimer: This briefing note contains the encapsulation of views presented by the speaker and does not exclusively represent the views of the Canadian Association for Security and Intelligence Studies.

\section{KEY EVENTS}

On November 27, 2020, Viveca S. Greene presented The Use of Memes and Satire by the Alt-right and Gen Z Activists - Exclusion vs Inclusion at the 2020 CASIS West Coast Security Conference. The presentation was followed by a group panel for questions and answers. Main discussion topics included humour studies, the Alt-Right, satire, and memes.

\section{NATURE OF DISCUSSION}

\section{Presentation}

Dr. Greene conceptualized the link between humour studies and alt-right extremism; memes and dark humour; and how humour is used to disseminate extremist sentiments.

\section{BACKGROUND}

\section{Presentation}

Through examining various memes in a chronological order, using the 2016 United States presidential election as a starting point, Dr. Greene illustrated how the alt-right uses memes and satire to disseminate values. The political environment allows opportunities for humour to be used as a tool to share more extremist narratives. The four tools of satire used to promote extremist messaging are aggression, play, laughter, and judgment. This can result in memes and images that seem humorous but contain violent and graphic messaging. In many cases where memes seem harmless, they are instead effective invitations to white supremacist ideology and provide clues into who is embracing those ideologies, along with perhaps how to embrace it as well. 
An increase in these memes can result in humour which can potentially allow for the relaxation of norms around extremist sentiments. Social psychology research suggests that if one holds racist views themselves, they become more likely to tolerate discriminatory actions and speech; and arguably, they potentially participate when exposed to disparaging humour. Memes created by the alt-right are intended to "red pill normies", which means that they are designed to wake up those suffering from the alleged false consciousness of liberal thinking, represented by the blue pill. Through this perspective, the alt-right and memes go together like peanut butter and jelly that has been spread into a swastika.

As social interaction has moved online, especially in recent months, memes have become an increasingly common method of establishing one's political subjectivity; increasing one's social capital; and receiving the likes and affirmation that people have become so dependent on within their own online communities. While memes may not be inherently right-wing extremist vessels, they remain vessels which have the opportunity to travel and influence people.

\section{KEY POINTS OF DISCUSSION}

\section{Presentation}

- Satire and humour are tools used to share extremist messaging in subtle ways.

- An increase in memes that normalize hateful humour can potentially allow for relaxation of norms around extremist sentiments.

- Memes remain vessels that can travel and influence people.

(c) (1) ()

EY NC ND This work is licensed under a Creative Commons AttributionNonCommercial-NoDerivatives 4.0 International License.

(C) (Viveca S. Greene, 2021)

Published by the Journal of Intelligence, Conflict, and Warfare and Simon Fraser University

Available from: https://jicw.org/

The Journal of Intelligence, Conflict, and Warfare 